\title{
Poverty's Agent: The Framing of Poverty and Responsibility in Colombian Newspapers
}

\author{
Margrete Dyvik Cardona
}

\section{Introduction}

Without making any specific claim about the humanities' responsibility in relation to social relevance, this article offers an example of a linguistic research project that has been driven precisely by the desire to address a specific social problem.

In concrete terms, we aim to examine, by way of linguistic analyses, to whom or what the Colombian newspapers assign notions of responsibility, cause or blame when they address the topic of poverty. It is our assumption that specific attitudes may reveal themselves in linguistic patterns (among other things). Here, we examine the verbs that appear in connection with the word pobreza (poverty) as syntactic and semantic argument. In particular, we examine the agent, or highest argument (explained below) of the various verbs in detail, since the agent is the initiator of the verbal action, and therefore has the potential of accepting responsibility or blame for the action described.

The analysis considers the topic primarily from a quantitative perspective, in that features will be classified and counted (McEnry and Wilson 1996, 76). However, the analysis is also qualitative in nature, because, according to Susan Conrad (2002):

all studies include both aspects of analysis to some extent. Recognizing patterns of language use necessarily entails assessing whether a phenomenon is common or unusual-a quantitative assessment. At the 
same time, numbers alone give little insight about language. Even the most sophisticated quantitative analyses must be tied to functional interpretations of the language patterns. (Conrad 2002, 78)

This study is a contribution to the cross-disciplinary project POLAME, (Poverty, Language and Media), whose objective is "to study the language used by the most important newspapers in Mexico, Brazil, Argentina and Colombia to construct and convey the notions of poverty" (UiB 2016). The project has compiled an electronic linguistic corpus comprised of newspaper articles on poverty from the four countries included in the research project.

The present study is limited to the Colombian newspapers in the polame-corpus (El Tiempo, El Espectador, El Colombiano), and to verbs that have pobreza as part of their subcategorization. ${ }^{1}$ Thus, adverbials and other adjuncts ${ }^{2}$ have not been taken into account.

In the subsequent sections (2.1-2.2), we review relevant theories related to thematic roles, grammatical voice, lexical aspect and the influence of agenda-setting media.

\section{Theoretical considerations}

\subsection{Argument structure, voice and lexical aspect}

From a linguistic standpoint, the examination of a predicate's argument structure represents a formal, efficient and measurable way of identifying and analysing the participants of the event described by the verb. This, in turn, is an indispensable step in the quest for a responsible/culpable party for the concerns addressed by the relevant predicates.

The present paper will employ Lexical-Functional Grammar's (LFG) descriptive apparatus for the identification and classification of various kinds of verbs and their arguments. We have chosen this framework because we will be reviewing the relationship between syntactic argu-

1 The term subcategorization is used in Lexical-Functional Grammar ( $L F G$ ) theory "to refer to the set of grammatical relations which are specified in a verb's lexical entry" (Kroeger 2008,17 ). The lexical entry of a word "contains information about the meaning, pronounciation, and grammatical features of that particular word" (Kroeger 2008,14 ).

2 An adjunct is "a kind of phrase [that] can be added freely to virtually any clause that describes an event" (Kroeger 2008,7 ). Thus, an adjunct is not an argument of the predicate (Kroeger 2008,14 ). 
ments and semantic roles, and the LFG framework is designed to give in-depth accounts of precisely this relationship, among others. LFG operates with three different levels of representation for sentence structure: a(rgument) structure, which deals with predicate-argument information, such as Agent, Patient or Theme; f(unctional) structure, which deals with functional information such as SUBJ and овJ (Austin 2001, 5); and $c$ (onstituent) structure, which is the overt surface phrasal syntactic representation (Dalrymple 2001, 45).

In the search for an agent and/or a responsible party for the verb action, it is the argument structure that is the most central level. Finocchiaro, Capasso, Cattaneo, Zuanazzi, and Miceli $(2015,223)$ state that "'argument structure' captures the idea that verbs denote relations between entities, and their role in the event is completely independent of the specific words used." Thus, the argument structure of a verb like combatir (combat), which appears frequently in the corpus with the word pobreza as argument, could be represented in the following manner:

combatir <agent, patient>

Fig. 1. Argument structure of combatir

Furthermore, the predicate is associated with specific grammatical relations that are linked to the arguments that make up the argument structure. The mapping of the relationship between the semantic roles (in the a-structure) and grammatical (in the f-structure) is referred to as linking (Kroeger 2008, 17), and can be represented in the following manner:

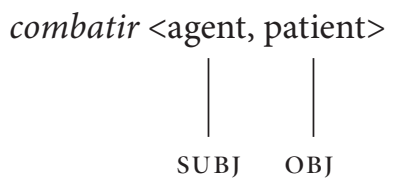

Fig. 2. Linking

Figure (2) illustrates the fact that for combatir, its agent-role (see definition below) appears in the subject position in an unmarked sentence, and that the patient-role appears in the object-position. This means that the identification of the syntactic arguments (f-structure) of the verbs in the corpus also makes their semantic arguments (a-structure) accessable. 
Kroeger $(2008,9)$ proposes an inventory of ten thematic roles, eight of which have been identified in the present analysis: ${ }^{3}$

AGENT: causer or initiator of events

EXPERIENCER: animate entity which perceives a stimulus or registers a particular mental or emotional process or state RECIPIENT: animate entity which receives or acquires something BENEFICIARY: entity (usually animate) for whose benefit an action is performed

INSTRUMENT: inanimate entity used by an agent to perform some action

THEME: entity which undergoes a change of location or possession, or whose location is being specified

PATIENT: entity which is acted upon, affected, or created; or of which a state or change of state is predicated STIMULUS: object of perception, cognition, or emotion; entity which is seen, heard, known, remembered, loved, hated, etc.

LOCATION: spatial reference point of an event

ACCOMPANIMENT (or COMITATIVE): entity which accompanies or is associated with the performance of an action

The interaction between these thematic roles and the various kinds of verbs that subcategorize for them, is accounted for in part by the thematic hierarchy, which is a hierarchy of relative prominence for the thematic roles (from left to right) (Bresnan 2001, 307). In other words, this hierarchy ranks the thematic roles with respect to their likelihood of functioning as logical subject (Austin 2001, 13). The hierarchy is as follows:

Agent $>$ beneficiary $>$ experiencer/goal $>$ instrument $>$ patient/theme $>$ locative (Bresnan 2001,307)

This hierarchy has turned out to be especially relevant for the explication of cases where thematic roles other than the agent function as subject, such as the passive and middle voices.

3 The two thematic roles not identified in the corpus scrutiny were BENEFICIARY and ACCOMPANIMENT. 
For the identification of agent/responsible party for the predicates that appear with pobreza, it is also necessary to classify the agent roles according to their degree of animacy. This is because an inanimate entity, even if it has the potential of denoting cause, cannot be assigned blame or responsibility. Hence, the agents of the different predicates have been classified, among other things, according to Silverstein's animacy hierarchy, as presented by Deane $(1987,67)$ :

$1^{\text {st }}$ person pronoun $>2^{\text {nd }}$ person pronoun $>3^{\text {rd }}$ person pronoun $>3^{\text {rd }}$ person demonstrative $>$ Proper name $>$ Kin-Term $>$ Human and animate NP $>$ Concrete object $>$ Container $>$ Location $>$ Perceivable $>$ Abstract

For our analysis, we have added a further distinction: plural NPs are lower on the animacy scale than singular NPs, because number has been identified as a feature that influences the animacy of an NP (Bianchi $2006,2025)$, and also because the ascription of blame to collective entities is questionable (Pizarro 2014, 234).

Furthermore, since animacy correlates with the aforementioned concept of prominence (shown in the thematic hierarchy), in that agents typically are high in animacy (Fauconnier 2011, 534), the analysis will examine the frequency with which inanimate agents appear with the different predicates. This is relevant because inanimates are not expected, crosslinguistically, to occur as agents (Pizarro 2014, 533), and because they cannot accept blame.

In addition, it will be necessary to examine a specific kind of predicate that does not allow the identification of an agent argument at all. This is the middle voice, made up of unaccusative predicates (García-Miguel 1985,323 ), and it is distinguished not only by the absence of an agent, but also by the impossibility of including one; nobody can be implicated as initiator of the process described by the predicate (García-Miguel 1985, 323). This is different from the passive voice, in which the predicate is analysed as having a suppressed agent argument (Austin 2001, 16). This means that, in the case of the middle voice, the verb has a complete argument structure in which the highest argument is some argument other than the agent, whereas for the passive voice, the predicate has an "in- 
complete" argument structure, because the agent argument has been suppressed.

There is a third semantic distinction (in addition to argument structure and voice), which is important for the linguistic examination of the ascription of blame, and that is lexical aspect. This is relevant not only because it intersects with argument structure and linking at the lexicalsemantic interface (Filip 2012, 721), but also because it reflects what the prospective agent is held responsible for. For example, is he held responsible for eliminating poverty, or simply for combatting it? In the first case, the verb is telic, while in the second case it is atelic. According to Filip $(2012,721)$, “Telic verbs express 'an action tending toward a goal', while atelic ones describe situations that 'are realized as soon as they begin'[...]" One specific prediction related to telic and atelic predicates is relevant to our study, and that is the fact that they "yield different patterns in the ordinary [...] progressive: an atelic predicate $V$ should licence the inference from the progressive to the perfect ( $X$ is Ving entails that $X$ has $V e d$ ), while a telic predicate should not ( $X$ is Ving does not entail $X$ has Ved)" (Marín \& McNally 2011, 485). In other words, X está combatiendo la pobreza ${ }^{4}$ entails $X$ combatió/ha combatido la pobreza, ${ }^{5}$ but X está eliminando la pobreza ${ }^{6}$ does not entail X eliminó/ha eliminado la pobreza.7

Hence, the predicates found in the corpus will not only be classified according to argument structure and voice, but also according to lexical aspect.

\subsection{Media influence on public perception}

Since the aim of the POLAME project is to ascertain how the agenda-setting media portray poverty, i.e. whether they instil a notion of poverty in the mind of the public that makes it difficult to combat it, it is necessary to consider previous studies that have examined measurable effects on the public of different media portrayals.

Several scholars have found that there is indeed an influence. Wanta, Golan and Lee $(2004,364)$ state that "under certain circumstances, the news media do tell people what to think by providing the public with an

$4 X$ is combatting poverty (all translations are my own).

$5 X$ has combatted poverty

$6 X$ is eliminating poverty

$7 \quad X$ has eliminated poverty 
agenda of attributes - a list of characteristics of important newsmakers." Shanto Iyengar $(1990,19)$ addresses the issue of poverty specifically, and claims: "How people think about poverty is shown to be dependent on how the issue is framed." Martin Gilens $(1996,528)$ declares that "past research has shown that the mass media can exert a powerful influence on public perceptions and attitudes [...]."

Chauhan and Foster $(2014,391)$ employ the Social Representations Theory (sRT) to explain how this influence works: "The theory rejects the notion of knowledge being a facsimile of some objective event or a mere description of events in the social world. Instead, it considers knowledge to be produced through acts of communication that are guided by the interests of the people involved." This is important, because " $t$ the role of public opinion in democratic societies is critical, since it can influence governmental responses to social problems" (Chauhan \& Foster 2014, 401).

The aim of the present paper is not to measure the public's response to the way Colombian newspapers' frame poverty, although we operate under the assumption that what we observe here could influence the way the community perceives this pervasive social challenge.

\section{Analysis}

\subsection{Method}

The present analysis, like the POLAmE project as a whole, uses a linguistic corpus as its empirical basis. The POLAME-corpus is an annotated, searchable compilation of newspaper articles about poverty, from Brazil, Colombia, Agentina and Mexico. It comprises 37 million words, with articles assembled between the years 2000 and 2014. The use of a confined linguistic corpus is of great value for many different kinds of linguistic investigation, because it allows the investigator to carry out exhaustive, linguistically itemized searches on excerpts of authentic language, taking into account all relevant examples, not only those that conform to some pre-conceived hypothesis.

Furthermore, it has been shown that corpus linguistic techniques have been "important for discerning the strong associations that exist between the lexicon and grammatical structures" (Chauhan \& Foster 2014, 81), and voice and argument structure, which are what we are focusing on here, are concerned precisely with the association between the lexicon and grammatical structures. 
One of the greatest benefits of an electronically stored linguistic corpus, however, is the fact that it is possible to conduct large-scale searches on massive chunks of text in an automated and efficient manner. For the present analysis, this means that we have been able to identify each and every instance in which a verb co-occurrs with the lexeme pobreza.

There are, nevertheless, a great many linguistic phenomena that do not lend themselves to automated retrieval. These include the identification and delimitation of a verb's argument structure and voice, as well as the lexical aspect of predicates. A substantial part of the corpus search for the present analysis, therefore, has been conducted manually. This has precluded the possibility of a comprehensive search of the whole corpus, and that is the reason why this paper is limited to the Colombian newspapers. Annelie Ädel $(2014,68)$ states: "it is often not doable to examine a full set of data qualitatively. An important issue, then, is how to select a subset for further qualitative analysis." The makeup of the POLAmEcorpus allows us to select a natural subset, since the corpus is divided into geographical domains.

Hence, our search has been conducted in the following manner: Firstly, the corpus was searched for all strings that contained a verb with the lexeme pobreza as one of the five ${ }^{8}$ words to the right or to the left of it. The next step was to manually examine the search results to discard any instances in which the lexeme poverty was not an argument of the verb. All the remaining verbs were registered and counted individually. Subsequently, the most frequently used verbs were grouped together according to their subcategorization and voice. This step also involved identifying what thematic role the lexeme pobreza displayed in each case. Thereafter, the agents of these verbs were examined in further detail to ascertain specifically what kind of entities filled the agent role in each case (see section 3.2 for the specifications).

The following section presents the results of this analysis.

\subsection{Results}

There are 1564 cases in total of verbs that appear with pobreza as argument. These cases represent 82 different verbs. For these verbs, pobreza is either the direct object, the subject (of a passive or an active verb), the indirect object, or a prepositional object. The most frequent verbs to oc-

\footnotetext{
8 This number is a direct result of the corpus' search interface.
} 
cur with pobreza as argument, are the following (the number to the right of each verb indicates its number of occurrences):
1. Reducir (reduce) (356)
2. Combatir (combat) (135)
3. Disminuir (diminish/reduce) (96)
4. Aumentar (increase) (88)
5. Superar (get past) (78)
6. Erradicar (eradicate) (78)
7. Medir (measure) (53)
8. Tener (have) (52)
9. Acabar (end) (45)
10. Caer (fall) (42)
11. Luchar (fight) (34)
12. Eliminar (eliminate) (33)

These twelve verbs are the ones whose argument structures will be scrutinized in further detail here.

In order for the analysis of the verbs' argument structures to be relevant for the issue of responsibility framing, we must also classify the verbs according to what kind of action they hold the agent responsible for. For instance, the agent of a verb like tener should not be grouped together with the agent of a verb like eliminar, because they are not performing the same kind of action (or any action at all, in the case of tener).

The analysis of the corpus occurrences has yielded the following four relevant semantic categories for the twelve verbs analysed. Some of the verbs may be categorized as belonging to more than one semantic category, depending on context.
a) Verbs that refer to solving poverty
Example: "[...] ya es hora [...] de que su multibillonario Departamento de la Prosperidad Social empiece a erradicar la pobreza [...]." (Quiroz and Tamayo 2014)

\footnotetext{
9 "[...] it is time [...] that their multibillionaire department of social prosperity starts to eradicate poverty [...]." (Quiroz and Tamayo 2014).
} 
b) Verbs that refer to cause/culpability for poverty

Example: “[...] la crisis global de 2008-09 ha aumentado la pobreza y el desempleo [...].” (Quiroz and Tamayo 2014)

c) Verbs that describe measurement/definition of poverty

Example: "[...] hoy los indicadores que miden la pobreza no se limitan a reviser los ingresos del hogar."11 (Quiroz and Tamayo 2014)

d) Verbs that describe an agentless rise or fall in poverty

Example: "Desde 2002 la pobreza en América Latina ha caído 15,7 puntos porcentuales..." ${ }^{\prime 2}$ (Quiroz and Tamayo 2014)

Table 1. The semantic categories of the verbs

a) Solving poverty

\begin{tabular}{|c|c|c|c|c|c|}
\hline Telic & Atelic & & & Telic & Atelic \\
\hline Eliminar (33) & Reducir (356) & Aumentar (16) & Medir (53) & Acabar (1) & Caer (42) \\
\hline Erradicar (78) & Combatir (135) & & Tener (52) & & Aumentar (72) \\
\hline Superar (78) & Disminuir (54) & & & & Disminuir (42) \\
\hline Acabar (44) & Luchar (34) & & & & \\
\hline
\end{tabular}

All in all, these verbs constitute 1090 cases, which were analysed in detail. $74 \%$ (812 cases) were instances of verbs referring to solving poverty, $1.5 \%$ (16 cases) referred to cause or culpability, $10 \%$ (105 cases) described measurement or definition, and 14\% (157 cases) described an agentless rise or fall in poverty.

The subsequent step of our analysis involves the examination of each verb's agent argument, or rather the argument highest on the thematic hierarchy (see section 2.1). The following modifications to the Silverstein hierarchy (Deane 1987, 67) were made based on our analysis:

a) The three specifications "1st person pronoun $>2$ nd person pronoun $>3$ rd person pronoun" have been reduced to "personal pronoun $\mathrm{sg}>$ per-

10 "[...] the global crisis of 2008-2009 has increased poverty and unemployment [...]." (Quiroz and Tamayo 2014).

11 "[...] today, the indicators that measure poverty are not limited to revising household income" (Quiroz and Tamayo 2014).

12 "Since 2002 , poverty in Latin-America has declined by 15.7 percentage points..." (Quiroz and Tamayo 2014). 
sonal pronoun pl," since all personal pronoun agents in the corpus are 1st person plural.

b) The $3^{\text {rd }}$ person demonstrative, kin-term and concrete object as agents have been eliminated, since they do not appear in the corpus.

c) Singular entities have been placed higher on the scale than plural ones, since our definition of animacy is motivated by our desire to identify a responsible or culpable party, and assigning culpability to a plural entity is questionable (Pizarro 2014, 234).

d) The categories "proper name" and "human and animate NP" have been conflated here, because they have the same kind of reference in the corpus.

\section{Amended animacy hierarchy}

Singular personal pronoun $>$ Singular human and animate NP (including proper names) $>$ Plural personal pronouns $>$ Plural human and animate NPs $>$ Container $>$ Location $>$ Perceivable $>$ Abstract

The following kinds of agent were identified in the corpus, with the concepts from the amended animacy scale specified in parenthesis to the right:

Animate agents (from most animate to least animate)

a) One concrete person. (singular human and animate NP)

Example: "El presidente de Chile, Sebastián Piñera, afirmó hoy que el progreso económico alcanzado por su país le permite estar en condiciones para erradicar la pobreza y la desigualdad..."13 (Quiroz and Tamayo 2014).

b) "Nosotros," "us" pronounced by a representative of a specific group. (plural personal pronouns)

Example: "Hoy venimos a Quibidó a enfrentar la realidad junto a ustedes, decididos a combatir la pobreza extrema desde la zona..." ${ }^{\prime 4}$ (Quiroz and Tamayo 2014)

13 "The president of Chile, Sebastián Piñera, affirmed today that the economic progress his country has achieved puts it in a situation to eradicate poverty and inequality" (Quiroz and Tamayo 2014).

14 "[...] today we come to Quibidó to face reality together with you, [and we are] com- 
c) "Nosotros," "us" general. (“Us" as citizens, or "us" as humans) (plural personal pronouns)

Example: "Es un discurso que afirma que si queremos algún día salir del subdesarrollo, eliminar la pobreza y disminuir drásticamente la desigualdad, Colombia demanda en muchas áreas unas políticas, no de gobierno, sino de Estado"15 (Quiroz and Tamayo 2014).

d) Group of people, plural form (plural human and animate NPs). Example: "En los últimos diez años los vietnamitas han logrado reducir la pobreza en un 67\%..."16 (Quiroz and Tamayo 2014).

e) People in general. (plural human and animate NPs) "[...] algunos querrán matar a los pobres para acabar con la pobreza o eliminar a los ricos..." ${ }^{\text {17 }}$ (Quiroz and Tamayo 2014).

Inanimate agents (from most animate to least animate)

f) Organization (political, religious or ideological) (container). Example: "El gobierno de Santos hizo lo que ningún otro había podido o querido. Acabar con la pobreza en Colombia"18 (Quiroz and Tamayo 2014).

g) Geographical or administrative area (location).

Example: "América Latina afronta el desafío de evitar la violencia de género, disminuir la pobreza, adaptarse al cambio climático..."19 (Quiroz and Tamayo 2014).

mitted to combatting extreme poverty in the zone..." (Quiroz and Tamayo 2014).

"It is a discourse which affirms that, if we one day want to overcome our underdevelopment, eliminate poverty and drastically reduce inequality. Colombia demands policies in many areas, not governmental policies, but state policies" (Quiroz and Tamayo 2014).

16 "In the last ten years the Vietnamese have succeeded in reducing poverty by $67 \%$ " (Quiroz and Tamayo 2014).

17 "[...] some will want to kill the poor in order to end poverty, or eliminate the rich..." (Quiroz and Tamayo 2014).

18 'Santos' government did what no other had been able or willing to. End poverty in Colombia” (Quiroz and Tamayo 2014).

19 "Latin-America faces the challenge of avoiding violence against women, reducing poverty, adapting to climate change..." (Quiroz and Tamayo 2014). 
h) Scale of measurement (perceivable).

Example: "Según el coeficiente Gini, que mide el nivel de pobreza por la concentración del ingreso en la ciudad, [...]"2o (Quiroz and Tamayo 2014).

i) Process or activity (abstract).

Example: "Según el presidente, el crecimiento económico, que este año será del orden del $4,5 \%$, tiene un gran impacto social pues 'está reduciendo las desigualdades, está reduciendo la pobreza, [...]"21 (Quiroz and Tamayo 2014).

j) Social phenomenon (abstract).

Example: "La Organización Mundial del Turismo (OMT) resaltó en la Cumbre de Johannesburgo, clausurada ayer, el creciente papel que el turismo puede jugar para erradicar la pobreza y lograr el desarrollo

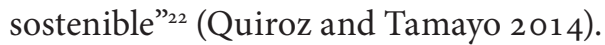

k) Social program (abstract).

Example: "El mejor camino es adoptar un nuevo modelo que rectifique los desvaríos neoliberales y contribuya a erradicar la pobreza y reducir las desigualdades"23 (Quiroz and Tamayo 2014).

The results of the analysis show that: of the agents of the telic verbs that refer to solving the problem (erradicar, eliminar, superar, acabar $(233$ cases)),

20 "According to the Gini coefficient, which measures levels of poverty according to the concentration of income in the city..." (Quiroz and Tamayo 2014).

21 "According to the president, the economic growth, which this year is $4.5 \%$, has a substantial social impact because 'it is reducing inequality, it is reducing poverty..." (Quiroz and Tamayo 2014).

22 "At the Johannesburg summit, which ended yesterday, the World Tourist Organization emphasized the increasing role that tourism may play in the eradication of poverty (e.g. to eradicate poverty) and in achieving sustainable development" (Quiroz and Tamayo 2014).

23 "The best way forward is to adopt a new model, which rectifies the neo-liberal nonsense and contributes to eradicating poverty and reducing inequality" (Quiroz and Tamayo 2014). 
$32 \%$ are non-identifiable

$14 \%$ are a political, religious or ideological organization

$9 \%$ are singular persons

$6.5 \%$ are social programs

$6 \%$ are groups of people, in the plural form

$5 \%$ are a general us (citizens or human beings)

$5 \%$ are processes or activities

$5 \%$ are geographical or administrative areas

$3 \%$ are people in general

$2.5 \%$ are social phenomena

$1.6 \%$ are an $u s$, representative of a specific group

Of the agents of the atelic verbs that refer to solving the problem (reducir, disminuir, luchar, combatir (579 cases)),

$39 \%$ are non-identifiable

$14 \%$ are a geographical or administrative area

$12 \%$ are political, religious or ideological organizations

$7.5 \%$ are singular persons

$6.5 \%$ are processes or activities

$6 \%$ are social programs

$3.5 \%$ are groups of people, in the plural form

$3 \%$ are social phenomena

$2 \%$ are an $u s$ representative of a specific group

$1 \%$ are a general us (citizens or human beings)

$1 \%$ are people in general

Of the agents of the verbs that refer to cause or culpability (aumentar (16 cases)),

$44 \%$ are social phenomena

$39 \%$ are processes or activities

$11 \%$ are social programs

Of the agents/highest arguments of the verbs that describe measurement or definition of poverty (medir, tener (105 cases)), 
$34 \%$ are non-identifiable

$21 \%$ are geographical or administrative areas

$14.5 \%$ are the lexeme pobreza

$6 \%$ are general us (citizens or human beings)

$4 \%$ are singular persons

$4 \%$ are scales of measurement

$4 \%$ are political, religious or ideological organizations

$4 \%$ are NPs with pobreza as modifier

$3 \%$ are are groups of people, in the plural form

$2 \%$ are processes or activities

$1 \%$ are social phenomena

The highest argument of the telic verbs that describe an agentless rise or fall in poverty (only acabar, and only 1 case) is the lexeme pobreza.

Of the highest arguments of the atelic verbs that describe an agentless rise or fall in poverty (disminuir, caer, aumentar (156 cases)),

$83 \%$ are the lexeme pobreza

$17 \%$ are NPs with pobreza as modifier ${ }^{24}$

Before we extract the most important findings from the preceding overview, it is important to revisit the thematic hierarchy and consider how it accounts for the argument structure of some of these predicates. Some of the verbs that have received a detailed scrutiny of their highest argument, lack an agent argument altogether. This is the case for tener, caer, and some cases of acabar, disminuir and aumentar.

1) “Hasta 1995, la pobreza rural también cayó más rápidamente que la urbana..."25 (Quiroz and Tamayo 2014).

For all of these verbs, the highest, and only, argument, is the patient: "entity which is acted upon, affected, or created; or of which a state or change of state is predicated" (Kroeger 2008 , 9). Since the patient is the only argument in these cases, it is the only one that can be assigned the subject

24 The head of these NPs are the nouns cifra, nivel or indice.

25 "Until 1995, rural poverty also decreased (e.g. fell) more rapidly than urban poverty..." (Quiroz and Tamayo 2014). 
position. All these predicates, except for tener, are cases of the middle voice. Tener is not a case of the middle voice because it does not denote a process that affects the subject's referent (García-Miguel 1985, 323, RAE 2009, 3037-38), but rather a state.

In summary, the main findings of the present analysis are the following:

1) There are more than 16 times as many cases of verbs referring to solving poverty as there are of verbs referring to cause.

2) Among the verbs referring to solving the problem, there are more than twice as many atelic verbs as there are telic ones. In other words, mentions of combatting and minimizing poverty are far more frequent than mentions of eliminating or terminating it altogether.

3) For the verbs that referred to cause or culpability, none of the agents are animate.

4) $31 \%$ of all agents/highest arguments, for all of the verbs, are nonidentifiable.

5) For verbs referring to solving poverty, the most frequent agent arguments are political, religious or ideological organizations.

6) For verbs referring to cause or culpability, the most frequent agent argument is social phenomena.

7) The most frequent highest argument for verbs of measurement or definition is geographical area.

8) $19 \%$ of all of the verbs examined describe an agentless rise or fall in poverty.

\section{Conclusions}

The aim of the present article has been to use linguistic analysis to examine to whom or what Colombian newspapers assign notions of responsibility, cause or blame when they address the topic of poverty. Several scholars (Wanta, Golan \& Lee 2004 ; Iyengar 1990; Gilens 199 6; Chauhan $\&$ Foster 2014) have found that mass media can exert a powerful influence on public perceptions and attitudes. The present paper operates on the assumption that what we observe here could influence the way the community perceives this pervasive social challenge.

In order to ascertain how Colombian newspapers assign notions of responsibility, cause or blame, we have examined the verbs that appear 
with the word "pobreza" as syntactic and semantic argument. We have based the analysis on the LFG framework, and scrutinized the agent, or highest argument of the various verbs in detail, since the agent is the initiator of the verbal action, and thus has the potential to accept responsibility or blame for the action described.

For the identification of the agent/responsible party of the predicates that appear with pobreza, we classified the agent roles according to their degree of animacy, using a modified version of Silverstein's animacy hierarchy (Deane 1987, 67). An animacy ranking was deemed necessary because an inanimate entity, despite having the potential of denoting cause, cannot be assigned blame or responsibility.

The predicates' lexical aspect was also registered, both because it intersects with argument structure and linking at the lexical-semantic interface, and because it reflects what the prospective agent is held responsible for, an accomplished action, such as eliminate, or a process, such as combat.

The verbs were also subdivided into the following four semantic categories:

a) Verbs that refer to solving poverty

b) Verbs that refer to cause/culpability for poverty

c) Verbs that describe measurement/definition of poverty

d) Verbs that (lexically) describe an agentless rise or fall in poverty

The most important findings were:

1) There are more than 16 times as many cases of verbs referring to solving poverty as there are verbs referring to cause.

2) Among the verbs referring to solving the problem, there are more than twice as many atelic verbs as there are telic ones. In other words, mentions of combatting and minimizing poverty are far more frequent than mentions of eliminating or terminating it altogether.

3) For the verbs that refer to cause or culpability, none of the agents are animate.

4) $31 \%$ of all agents/highest arguments, for all the verbs, are non-identifiable. 
5) For verbs referring to solving poverty, the most frequent agent arguments are political, religious or ideological organizations.

6) For verbs referring to cause or culpability, the most frequent agent argument is social phenomena.

7) The most frequent highest argument for verbs of measurement or definition is geographical area.

8) $19 \%$ of all of the verbs examined described an agentless rise or fall in poverty.

It is worth noting that none of the verbs have arguments that refer to the general public's attitude towards poverty, i.e. their perception of it, which is the focal point for the POLAME-project. In other words, society's perception of the poor as victims or culprits, and the effects this view may have on the fight to overcome poverty, is not reflected in the verbal argument structure of the articles in the newspapers examined.

The present study could, and should, be used as a basis for a comparative scrutiny of the same phenomena for the other countries represented in the POLAME-project. It may also benefit from a supplementary study that takes into account a larger segment of the linguistic contexts in which the verbs considered occur.

\section{References}

Austin, Peter K. 2001. "Lexical Functional Grammar." In International Encyclopedia of the Social and Behavioral Sciences, edited by Neil J. Smelser and Paul Baltes, 8748-54. Amsterdam: Elsevier.

Bianchi, Valentina. 2006. "On the Syntax of Personal Arguments." Lingua 116 (12):2023-67.

Bresnan, Joan. 2001. Lexical-Functional Syntax, Blackwell Textbooks in Linguistics. Oxford: Blackwell Publishers.

Chauhan, Apurv, and Juliet Foster. 2014. "Representations of Poverty in British Newspapers: A Case of 'Othering'the Threat?” Journal of Community \& Applied Social Psychology 24 (5):390-405.

Conrad, Susan. 2002. "Corpus Linguistic Approaches for Discourse Analysis." Annual Review of Applied Linguistics 22:75-95.

Dalrymple, Mary. 2001. Lexical Functional Grammar. Vol. 34, Syntax and Semantics. San Diego: Academic Press. 
Deane, Paul. 1987. "English Possessives, Topicality, and the Silverstein Hierarchy." Paper presented at the annual Meeting of the Berkeley Linguistics Society.

Fauconnier, Stefanie. 2011. "Differential Agent Marking and Animacy." Lingua 121 (3):533-47.

Filip, Hana. 2012. "Lexical Aspect." In The Oxford Handbook of Tense and Aspect, edited by Robert I. Binnick, 721-51. Oxford: Oxford University Press.

Finocchiaro, Chiara, Rita Capasso, Luigi Cattaneo, Arianna Zuanazzi, and Gabriele Miceli. 2015. "Thematic Role Assignment in the Posterior Parietal Cortex: A tms Study.” Neuropsychologia 77:223-32.

García-Miguel, José M. 1985. "La voz media en español: las construcciones pronominales con verbos transitivos." VERBA 12:307-43.

Gilens, Martin. 1996. "Race and Poverty in America Public Misperceptions and the American News Media." Public Opinion Quarterly 60 (4):515-41.

Gómez, Torrego. 2002. Leonardo. Gramática didáctica del español. Madrid: Ediciones SM.

Iyengar, Shanto. 1990. "Framing Responsibility for Political Issues: The Case of Poverty." Political Behavior 12 (1):19-40.

Kroeger, Paul R. 2008. Analyzing Syntax: A Lexical-Functional Approach. Cambridge: Cambridge University Press.

Marín, Rafael, and Louise McNally. 2011. "Inchoativity, Change of State, and Telicity: Evidence from Spanish Reflexive Psychological Verbs." Natural Language \& Linguistic Theory 29 (2):467-502.

McEnry, Tony, and Andrew Wilson. 1996. Corpus Linguistics. Edinburgh: Edinburgh University Press.

Pizarro, David. 2014. "Androids, Algorithms, and the Attribution of Blame." Psychological Inquiry 25 (2):234-35.

Quiroz, Gabriel, and Antonio Tamayo. 2014. Polame Corpus. Medellín: Proyecto Polame.

RAE, ed. 2009. Nueva gramática de la lengua española. Madrid: Espasa Libros.

UiB. "Poverty Language and Media (POLAME)." http://www.uib.no/en/ project/polame (accessed 13 December 2016).

Wanta, Wayne, Guy Golan, and Cheolhan Lee. 2004. "Agenda Setting and International News: Media Influence on Public Perceptions of 
Foreign Nations." Journalism \& Mass Communication Quarterly 81 (2):364-77.

Ädel, Annelie. 2014. “Selecting Quantitative Data for Qualitative Analysis: A Case Study Connecting a Lexicogrammatical Pattern to Rhetorical Moves." Journal of English for Academic Purposes 16:68-80. 